\title{
長周期地震動用免震装置に関する研究
}

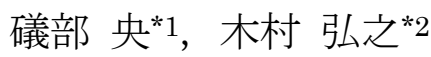

\section{Study on seismic isolation system for long-period ground motion}

\author{
${\text { Akira } \text { ISOBE }^{* 1} \text { and Hiroyuki KIMURA }}^{* 2}$ \\ ${ }^{* 1}$ Graduate School of Science and Engineering for Education, Toyama University \\ 3190 Gofuku, Toyama-shi, Toyama 930-8555, Japan \\ ${ }^{* 2}$ Graduate School of Science and Engineering for Research, Toyama University \\ 3190 Gofuku, Toyama-shi, Toyama 930-8555, Japan
}

\section{Received 14 December 2014}

\begin{abstract}
In this paper, the authors have developed a new type of horizontal seismic isolation system which has large effect of vibration isolation for ordinary earthquakes and suppresses the resonance of the isolation system due to long-period ground motions. This seismic isolation system is composed of coil spring and two slide rails. Further, an optimal frictional force is added to this system. The seismic isolation system adding the optimal frictional force is effective for suppressing the vibration of this system caused by short-period earthquakes and long-period earthquakes. Frictional force is used to suppress the resonance of the seismic isolation system. The trial seismic isolation table was made, and the effects of vibration suppression of the isolation table were discussed experimentally and numerically. In addition, we discussed the relation between optimal friction coefficient and maximum acceleration of the earthquake. We defined a parameter $\alpha$ as percentage of low frequency component in frequency response of earthquakes. As a result, it is shown that the optimal friction coefficient is in proportion to the corrected maximum acceleration of earthquake using parameter $\alpha$.
\end{abstract}

Key words : Seismic isolation, Isolation device , Long-period ground motion, Frictional vibration, Seismic response

\section{1. 緒言}

日本では 2000 年以降のみでも震度 5 弱以上の地震が 242 回 (気象庁, 2014), 年間で平均 17 回程度起こってい ることになる，建築物の地震対策としては，耐震，制震，免震といった方法がある．しかし，電子機器，精密機 械や美術品・工芸品等は耐震や制震といった地震対策をとるのは難しい. そのため様々な小型の水平および上下 免震装置が開発されている.これらのほとんどは $0.2 \sim 1$ 秒程度の短周期成分が卓越した地震動を対象としており， 高い免震効果を得るために, 免震装置系の固有周期を 2 5 秒程度に設定している場合が多い（若林他，2011）。 したがって，この固有周期成分を多く含む長周期成分が卓越した地震動を受けると免震装置系が共振し，許容変 位を大きく超えて振動する可能性がある．これらのことから短周期成分が卓越した通常の地震動には大きな免震 効果を有し，かつ長周期成分が卓越した地震動に対しては免震装置系の共振による過大変位を抑制することが求 められている.

長周期地震動による共振を防ぐためいくつかの研究が行われており，摩擦を地面と装置との相対変位に応じて 変化させ相対変位を抑制する方法（新谷他， 2006 ; 新谷, 服部, 2007 ; 新谷, 田中, 2008), 漸硬型摩擦ダンパを 用いて相対変位を抑制する方法 (若林他, 2011), 特殊交差形レール溝を用いて相対变位を抑制する方法 (清水他, 2014）等が提案されている. これらは相対変位の増加に伴い, 復元力や摩擦力を増加させるという方法である. この方法では相対変位の増加は防ぐことができるが，加速度の増加につながってしまうといった課題がある。

No.14-00679 [DOI:10.1299/transjsme.14-00679], J-STAGE Advance Publication date : 26 March, 2015

*1 学生員, 富山大学 大学院理工学教育部 (T930-8555 富山県富山市五福 3190)

*2 正員, 富山大学 大学院理工学研究部 (工学)

E-mail of corresponding author: hkimura@eng.u-toyama.ac.jp 
また, 摩擦係数を大きくすると相対変位が小さくなり応答加速度が大きくなること, 地震波の最大加速度が大 きくなると, 最適摩擦係数は大きくなる傾向を示し, この関係には直線的な傾向が見られると報告されている(新 谷, 服部，2007）。しかし，この検討で用いられた地震波のほとんどが短周期成分が卓越した地震動であり, 長周 期地震動についてはあまり検討されていない。

そこで本研究ではあらかじめ適切な摩擦力を付加し, 短周期成分が卓越した通常の地震動には大きな免震効果 を有し, 比較的加速度の小さい長周期地震動に対しては摩擦力で相対変位を抑制する免震装置を提案する.また, 地震波の最大加速度と免震装置の最適摩擦係数の関係について, 長周期地震動も考慮して検討する.

\section{2. 実 験 方 法}

\section{$2 \cdot 1$ 実験装置}

本研究で製作した免震装置の概略図を図 1 に, 諸元を表 1 に示寸. 免震装置は, ばね定数が $8[\mathrm{~N} / \mathrm{m}]$ のばねを 12 個, 図 1 のように接続し, 免震装置全体でばね定数 $24 \mathrm{~N} / \mathrm{m}$ となるように設計した. 免震装置の可動部分はステ ンレス製のパンチングメタルを使用し，2 本のリニアガイドで支持した. 具体的には内部に複数の鋼球が配置さ れたブロック 4 個（2 個 $\times 2 ）$ に可動部を固定する．このブロックが移動する際にリニアガイドとの間に摩擦力が 発生する. おもりと免震装置可動部の質量を合わせて $3.355 \mathrm{~kg}$ とし, 免震装置系の固有振動数を $0.42 \mathrm{~Hz}$ とし. また, 免震装置可動部の最大ストロークは両振幅で $120 \mathrm{~mm}$ である. 加振装置は THK（株）のマイホームぶるる 2 軸振動台を使用する。

\section{$2 \cdot 2$ 正弦波加振}

加振振幅 $15 \mathrm{~mm}(0-\mathrm{p})$ 一定で正弦波加振し, 定常状態で測定するために挙動が安定した 60 秒後に加速度およ び相対変位を測定する. 加速度は加速度計（KYOWA, AS-1GB）を免震装置可動部に取り付け測定し, 相対変位 は免震装置に取り付けた目盛りを読み取る。この測定を $0.1 \mathrm{~Hz}$ から $1.8 \mathrm{~Hz}$ まで, $0.1 \mathrm{~Hz}$ ごとに行い, 加速度およ び相対変位の周波数応答曲線を描く.

\section{$2 \cdot 3$ 地震波加振}

実験に使用した地震波を表 2 に示寸．それぞれの地震波は加振振幅 $30 \mathrm{~mm}$ (p-p) に基準化されている. それぞ れの地震波で加速度および相対変位の時刻歴応答を測定する. 加速度は加速度計（KYOWA, AS-1GB）を免震装 置可動部に取り付け測定する. 相対変位はビデオカメラを用い, 240 フレーム/秒で撮影した映像を Adobe Premiere Elements 2.0 により編集し，計測ソフトMoveTr2D を用いて画像解析し測定する.

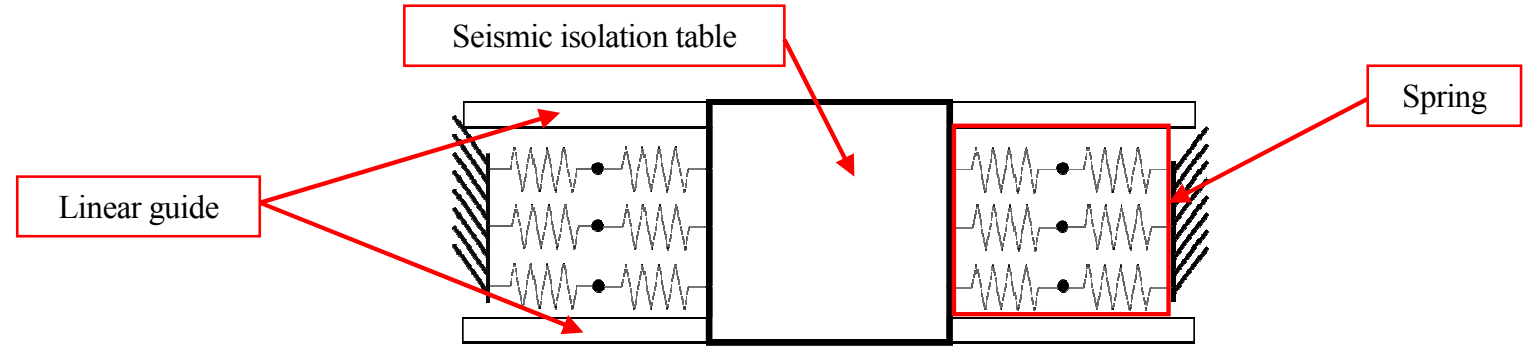

Fig.1 Overview of the seismic isolation system

Table 1 Specification of the seismic isolation table

\begin{tabular}{|l|cc|}
\hline Stroke $(p-p)$ & 120 & {$[\mathrm{~mm}]$} \\
\hline Table size & $120 \times 120$ & {$[\mathrm{~mm}]$} \\
\hline Mass of the moving part & 3.355 & {$[\mathrm{~kg}]$} \\
\hline Spring constant & 24 & {$[\mathrm{~N} / \mathrm{m}]$} \\
\hline Natural frequency & 0.42 & {$[\mathrm{~Hz}]$} \\
\hline Natural period & 2.35 & {$[\mathrm{sec}]$} \\
\hline
\end{tabular}


Table 2 Earthquake waves used in experiment (NS, EW; direction of earthquake waves)

\begin{tabular}{|l|l|}
\hline Earthquake (date) & Observation site \\
\hline Imperial Valley Earthquake_EW,NS (1940.5.18) & El Centro \\
\hline Kern County Earthquake_EW,NS (1952.7.21) & Taft \\
\hline The Iwate-Miyagi Nairiku Earthquake in 2008_EW,NS (2008.6.14) & Kurikoma \\
\hline The 1968 Tokachi-oki Earthquake_EW,NS (1968.5.16) & Hachinohe \\
\hline \multirow{2}{*}{ The Niigataken Chuetsu-oki Earthquake in 2007_EW,NS (2007.7.16) } & Ojiya \\
\cline { 2 - 2 } & Kashiwazaki \\
\hline \multirow{2}{*}{ Mid Niigata Prefecture Earthquake_EW,NS (2004.10.23) } & Tokamachi \\
\cline { 2 - 2 } & Ojiya \\
\hline The 1995 Southern Hyogo Prefecture Earthquake_EW,NS (1995.1.17) & JMA Kobe \\
\cline { 2 - 2 } & JR Takatori \\
\hline
\end{tabular}

\section{3. 解 析 方 法}

解析モデルを図 2 に示す．摩擦を考慮するとこの系の運動方程式は式（1）で表される.

$$
m \ddot{x}+c(\dot{x}-\dot{y})+k(x-y)+F_{d}=0
$$

ここで, $m$ は可動部質量（テーブル板，スライダ，テーブル上に積載したおもり）, $c$ は免震装置全体に存在する 減衰係数, $F_{d}$ は免震装置に付加する摩擦力, $x$ は装置の絶対変位, $y$ は入力変位を表す. 本報では図 3 に示す不連 続摩擦モデルを使用する（菊植他，2005)，摩擦力を表す式を式（2）に示す.

$$
F_{d}=\left\{\begin{array}{llcrr}
-h & \text { if } & v=0 & \text { and } & |h| \leq F_{s} \\
-\operatorname{sgn}(h) * F_{s} & \text { if } & v=0 & \text { and } & |h|>F_{s} \\
-\operatorname{sgn}(v) * F_{c} & & & & \text { otherwise }
\end{array}\right.
$$

ここで, $h$ は物体にかかる全外力 $(=-c(\dot{x}-\dot{y})-k(x-y)), v$ は相対速度 $(=\dot{x}-\dot{y}), F_{s}$ は静摩擦力, $F_{c}$ は動摩擦力, $s g n$ は符号関数である. 免震装置が停止している状態で全外力が最大静摩擦力以下の場合, 摩擦力を- $h$ (全外力を 打ち消す）とすることで静止状態（地面との相対変位が 0）を保つ. 免震装置が停止している状態で全外力が最 大静止摩擦力以上の場合, 摩擦力は最大静止摩擦力となる. 免震装置が動作している場合, 摩擦力は速度の方向 と反対に動摩擦力となる. 解析に用いた地震波を表 3 に示寸. No.1 から No.4 の地震波は日本建築センターの地 震波ダウンロード用ホームページより入手した. No.1 から No.3 は実地震波, No.4 は模擬地震波である. No. 5 か ら No.23 の地震波は独立行政法人防災科学研究所の強震観測網 K-net より入手した実地震波である. 時刻歴応答 解析にはニューマーク $\beta$ 法 $(\beta=1 / 4)$ を用いる.

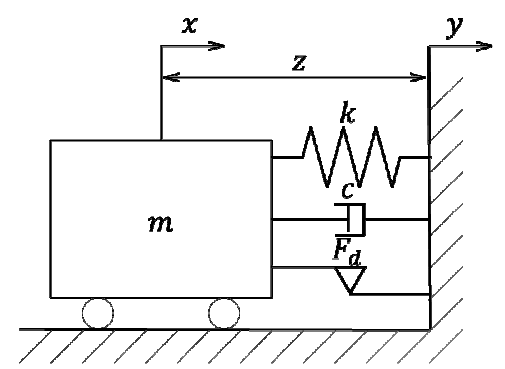

Fig.2 Simulation model of seismic isolation table

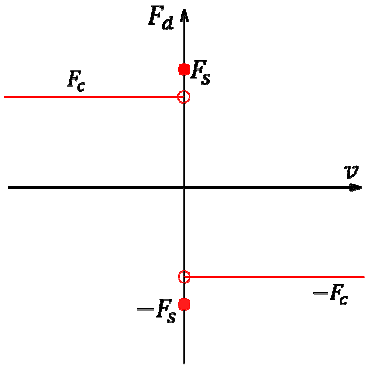

Fig.3 Friction model 
Table 3 Earthquake waves used in numerical calculation (NS, EW; direction of earthquake waves)

\begin{tabular}{|c|c|c|c|}
\hline No. & Earthquake (date) & Observation site (sy mbol) & Max. acc. $\times 10^{-2}\left[\mathrm{~m} / \mathrm{s}^{2}\right](\mathrm{Gal})$ \\
\hline 1 & Imperial Valley Earthquake (1940.5.18) & El Centro (ELC) & NS 341.7 \\
\hline 2 & Kern County Earthquake (1952.7.21) & Taft (TFT) & EW 175.9 \\
\hline 3 & The 1968 Tokachi-oki Earthquake (1968.5.16) & Hachinohe (HAC) & NS 229.6 \\
\hline 4 & Simulated Earthquake BCJ1 & $-(\mathrm{BCJ} 1)$ & 207.3 \\
\hline 5 & \multirow{2}{*}{ Earthquake Off-shore of Tokaido (2004.9.5) } & Nagoya (TAIC) & NS 52.7, EW 53.5 \\
\hline 6 & & Osaka (TOSK) & NS 25.3, EW 24.7 \\
\hline 7 & \multirow{2}{*}{ Mid Niigata Prefecture Earthquake (2004.10.23) } & Shinjuku (NTKY) & NS 14.9, EW 15.3 \\
\hline 8 & & Niigata (NNIG) & NS 468.5, EW 369.0 \\
\hline 9 & Earthquake Off-shore of Miyagi Prefecture (2005.8.16) & Shinjuku (MTKY) & NS 15.5 , EW 21.0 \\
\hline 10 & Earthquake under Northwestern Chiba Prefecture (2005.7.23) & Shinjuku (CTKY) & NS 51.1, EW 61.9 \\
\hline 11 & The 2005 West off Fukuoka Prefecture Earthquake (2005.3.20) & Fukuoka (FFKO) & NS 276.5, EW239.2 \\
\hline 12 & \multirow{3}{*}{ The 2011 off the Pacific coast of Tohoku Earthquake (2011.3.11) } & Nagoya (T2AIC) & NS 11.0, EW 9.6 \\
\hline 13 & & Osaka (T2OSK) & NS 7.3, EW 5.7 \\
\hline 14 & & Shinjuku (T2TKY) & NS 192.4, EW 166.4 \\
\hline 15 & Earthquake Off-shore of Miy agi Prefecture (2011.4.7) & Shinjuku (M2TKY) & NS 19.9, EW 20.9 \\
\hline 16 & Earthquake under Fukushima Prefecture Hamadoori (2011.4.11) & Shinjuku (F2TKY) & NS 26.3, EW34.3 \\
\hline 17 & Earthquake Off-shore of Miy agi Prefecture (1996.5.23) & Oshika (Oshika) & NS 567.9 \\
\hline 18 & Northern M iyagi Prefecture Earthquake (1996.8.11) & Naruko (Naruko) & NS 464.0 \\
\hline 19 & Mid Southern Tanegashima Earthquake (1996.9.9) & Nakatane (Nakatane) & NS 391.0 \\
\hline 20 & Earthquake in eastern Aichi Prefecture (1997.3.16) & Tsukude (Tukude) & NS 524.9 \\
\hline 21 & Northwestern Kagoshima Prefecture (1997.3.26) & Izumi (Izumi) & NS 727.3 \\
\hline 22 & Norhern Yamaguchi Prefecture Earthquake (1997.6.25) & Tsuwano (Tsuwano) & NS 421.3 \\
\hline 23 & Mid Southern Kushiro Region Earthquake (1999.5.13) & Chokubetsu (Chokubetsu) & NS 397.5 \\
\hline
\end{tabular}

\section{4. 結果および考察}

\section{$4 \cdot 1$ 正弦波加振}

正弦波加振試験の結果を数值解析の結果とともに図 4 に示す. 図中には，摩擦係数が 0 の場合の結果も示して いる. この図から加速度および相対変位ともに共振点付近では免震装置が摩擦力によって停止（加振装置との相 対変位が 0）していることがわかる. また，数值解析の結果と実験結果が良く一致していることが確認できた。 加振振幅一定（15[mm] 0-p） で正弦波加振を行っているため，加速度の小さい低周波数加振（加振周波数 $0.6 \mathrm{~Hz}$ まで）では加振加速度による慣性力が摩擦力より小さくなる。このため免震装置は停止し, 相対変位が 0 となる. 加振周波数が $0.7 \mathrm{~Hz}$ を超えると慣性力が摩擦力を上回り免震装置が動き出す.このように共振点付近で免震装置 を停止させることができれば，共振による相対変位の増大を抑制することができると考えられる.

正弦波加振実験に先だって行った静摩擦係数測定実験の様子と実験結果を図 5 , 図 6 に示す. おもりを載せた 免震装置可動部をばねで介して引っ張り，免震装置が動き出したときの引張力から静摩擦係数を算出する．可動 部分の質量が $3.355 \mathrm{~kg}$ で, 動き出したときの引張力が $0.994 \mathrm{~N}$ であったため, 静摩擦係数は 0.030 とした. 動摩擦 係数は静摩擦係数を 0.030 で固定し, 正弦波加振の実験と解析の加速度波形がどの周波数でも一致するように決 定した. 図 7 に正弦波加振実験時の加速度波形（一例として $0.4 \mathrm{~Hz}$ と $1.0 \mathrm{~Hz}$ ）を示す.この図より解析と実験の 結果は概ね一致していることがわかる.このときの動摩擦係数は 0.013 であった. 正弦波加振時の静摩擦係数と 動摩擦係数の比は 0.43 倍 $(=0.013 / 0.030)$ であった. 


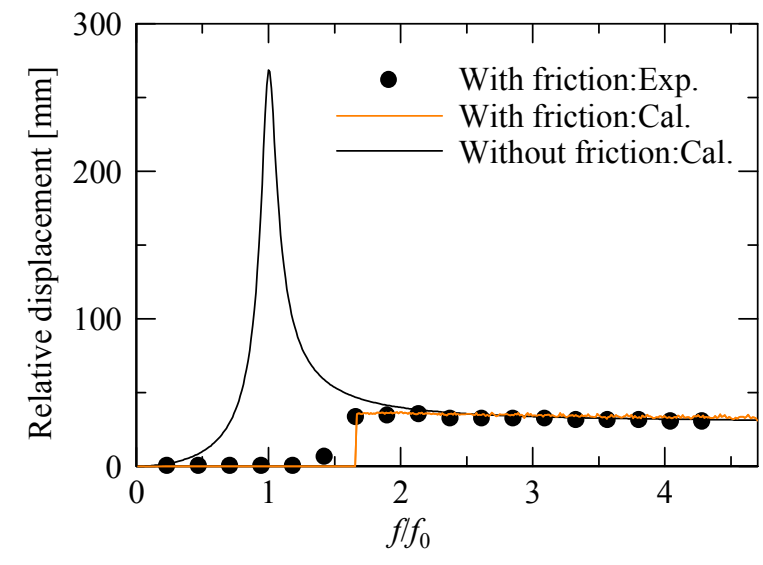

(a) Relative displacement

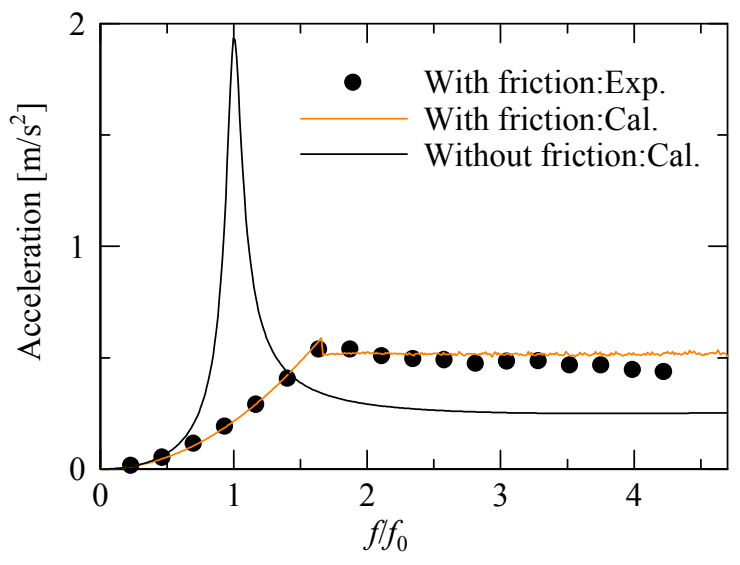

(b) Acceleration

Fig.4 Frequency response curves. Vibration frequency is normalized by the natural frequency of the seismic isolator. Seismic isolation is stopped in the vicinity of the resonance.

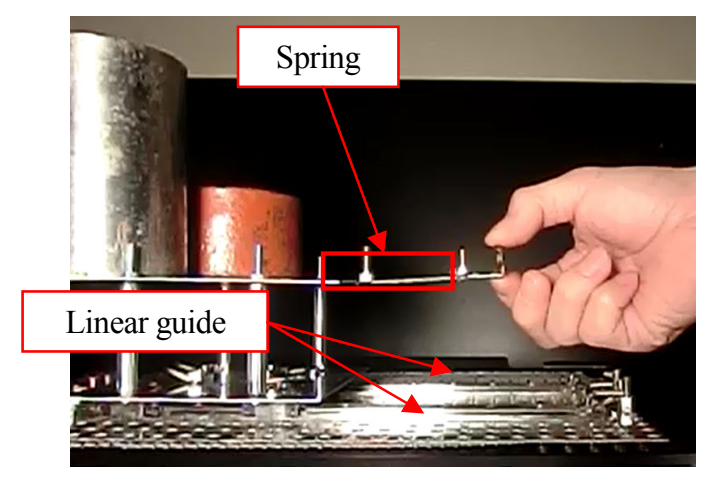

Fig.5 Experiment of static friction coefficient measurement

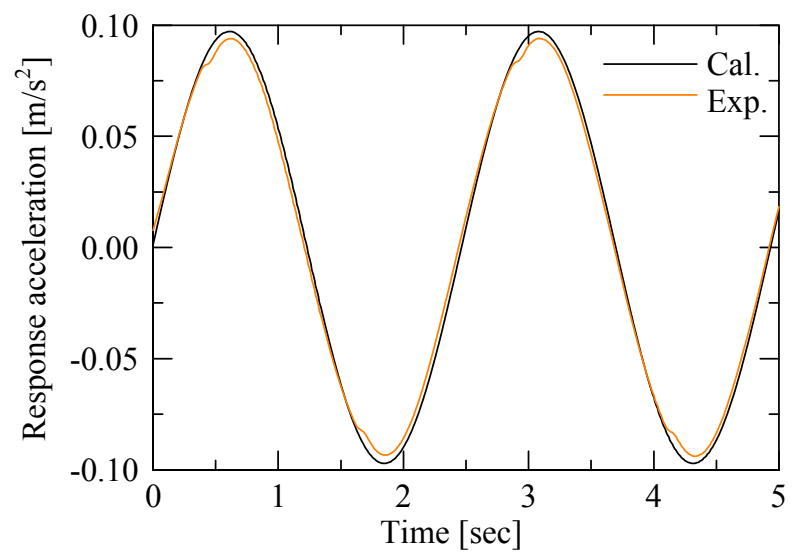

(a) $0.4 \mathrm{~Hz}$

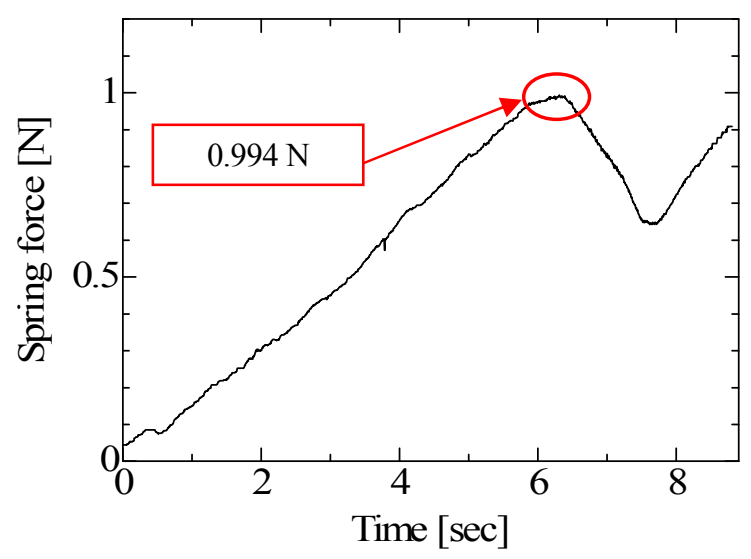

Fig.6 Static friction force. Static friction force is $0.994 \mathrm{~N}$.

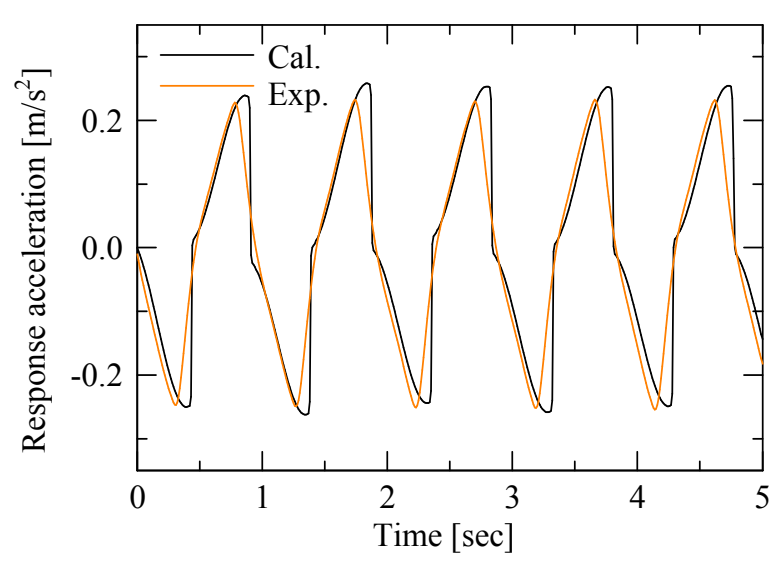

(b) $1.0 \mathrm{~Hz}$

Fig.7 Time history of response acceleration（Sine wave vibration）. Both the case of $0.4 \mathrm{~Hz}$ and $1.0 \mathrm{~Hz}$, calculated results agreed with experiment results. 


\section{$4 \cdot 2$ 地震波加振}

一例として地震波（Taft_EW，兵庫県南部地震（JR 鷹取）_EW）による加振試験の結果を数值解析の結果とと もに図 8, 図9, 図 10 に示寸. 図 9 は図 8 の加速度波形を $15 \mathrm{sec}$ から $20 \mathrm{sec}$ の範囲で拡大した図である. これら の図から加速度および相対変位の時刻歴波形についての実験と数值解析の結果は良く一致していることがわか る. なお，数值解析の静摩擦係数は正弦波加振実験の結果から 0.030 を用いた. また動摩擦係数については Excel のソルバー機能を使用し, 動摩擦係数を変化させ実験と数值解析の誤差が最小になるような動摩擦係数を用いた. Taft_EW，兵庫県南部地震（JR 鷹取）_EW の動摩擦係数はそれぞれ，0.0275，0.0176であった．この結果より数 值解析の妥当性が確認できた. その他の地震波の最大地震加速度と動摩擦係数の関係を図 11 に示寸. この図の横 軸は加振振幅を $30 \mathrm{~mm} \mathrm{p}$-p で基準化された地震波の最大加速度である. また, 赤い線は正弦波加振時の動摩擦係 数 0.013 を示している. 図 11 をみてわかるように地震波加振時の動摩擦係数は大きくばらついている. 従って以

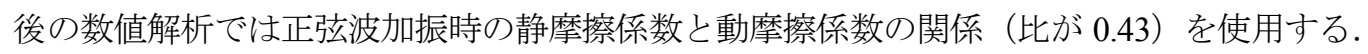

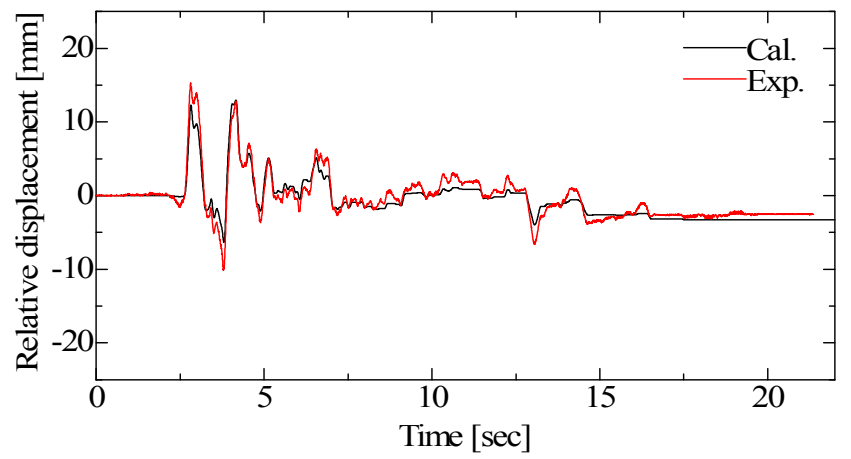

(a) Relative displacement

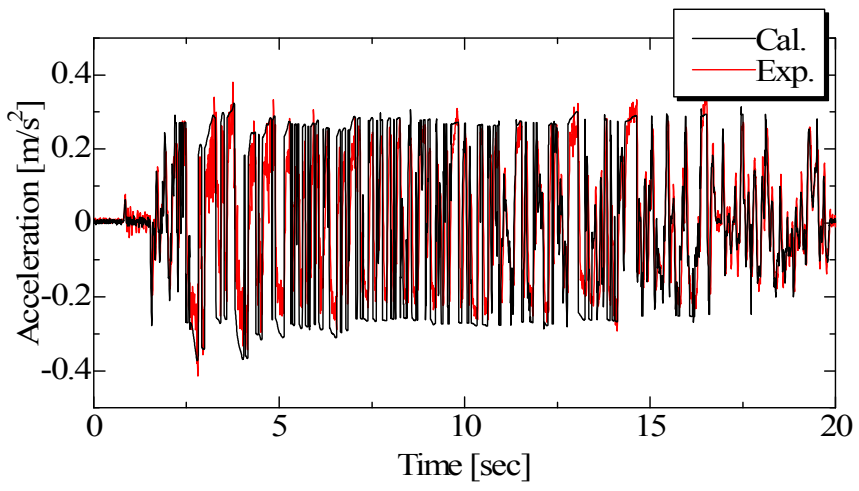

(b) Acceleration

Fig.8 Time history (Taft_EW). Both the case of relative displacement and acceleration , calculated results showed good agreement with the experimental results.

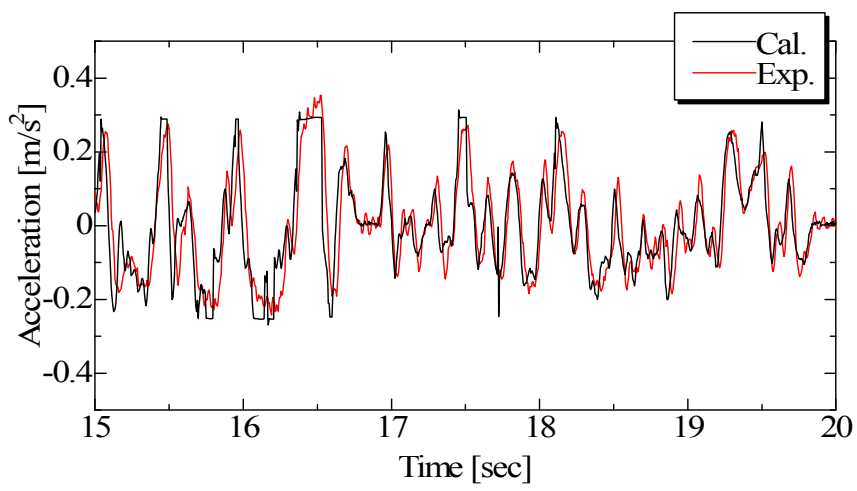

Fig.9 Expansion in the range of 15 seconds to 20 seconds. Both the case of relative displacement and acceleration, calculated results showed good agreement with the experimental results. 


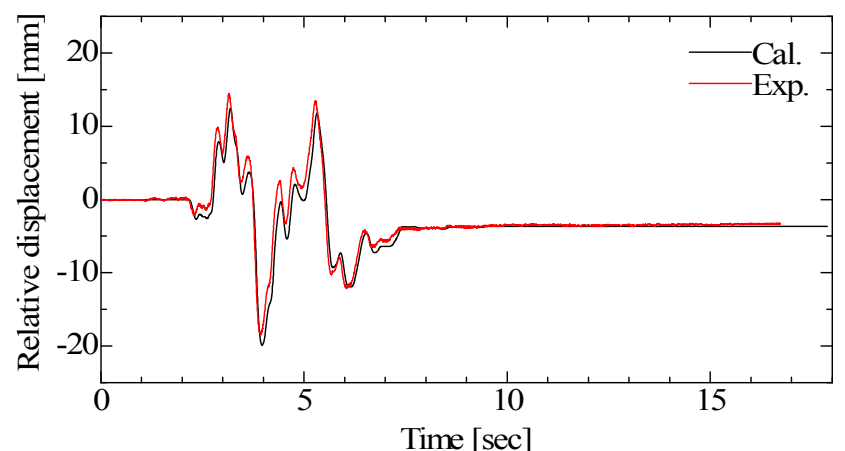

(a) Relative displacement

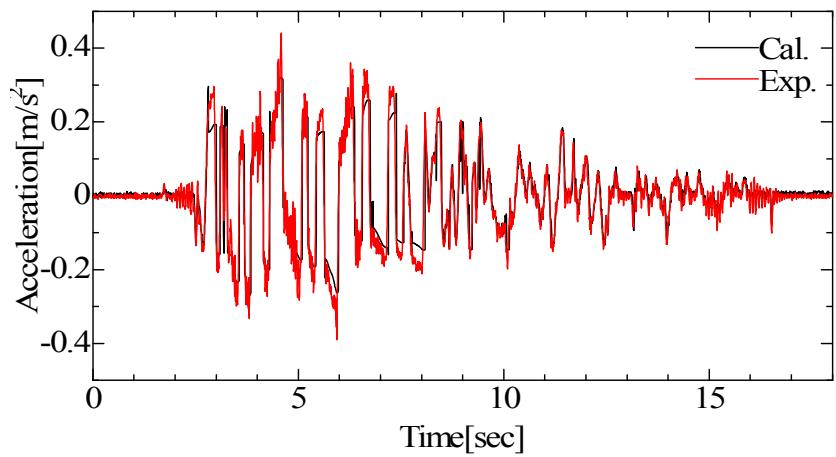

(b) Acceleration

Fig.10 Time history (JR takatori_EW). Both the case of relative displacement and acceleration , calculated results showed good agreement with the experimental results.

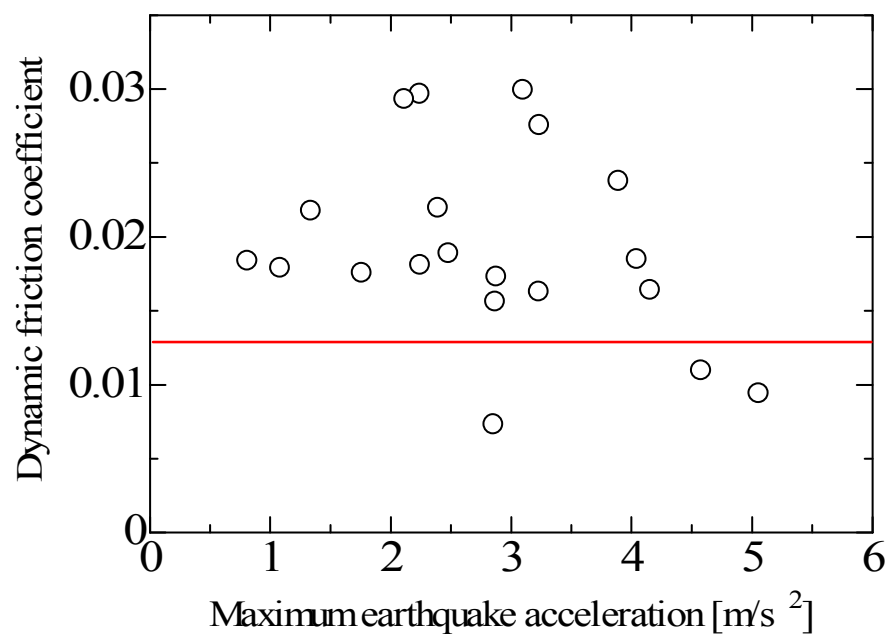

Fig.11 Dynamic friction coefficient.The red line shows the dynamic friction coefficient 0.013 obtained by sinusoidal vibration test.

\section{$4 \cdot 3$ 低周波数成分含有率 $\alpha$ の定義}

免震装置の共振成分が地震波にどの程度含まれているかを判断するために低周波数成分含有率 $\alpha$ という指標を 定義する. 図 12 に地震波の加速度応答スペクトルの一例を示寸. 本免震装置の加速度応答倍率が 1 を超える周波 数 $(0.6 \mathrm{~Hz}(=0.426 * \sqrt{2}))$ を本免震装置の共振する周波数帯とする. 各地震波の加速度応答スペクトルの免震装 置の低周波数成分含有部分の面積を $\mathrm{A}_{1}$ (図 12 の赤い斜線部分), $0.6 \mathrm{~Hz}$ から $10 \mathrm{~Hz}$ までの面積を $\mathrm{A}_{2}$ (図 12 の黒 い斜線部分）として $\alpha \%$ は式（3）で求める． $\alpha$ の值が大きいほど，長周期成分が多く含まれている地震動である ことを意味している. 


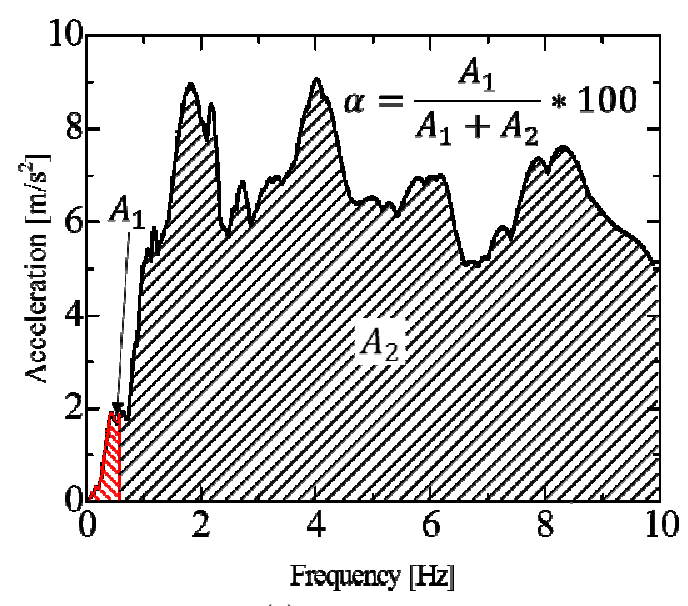

(a) ELCNS

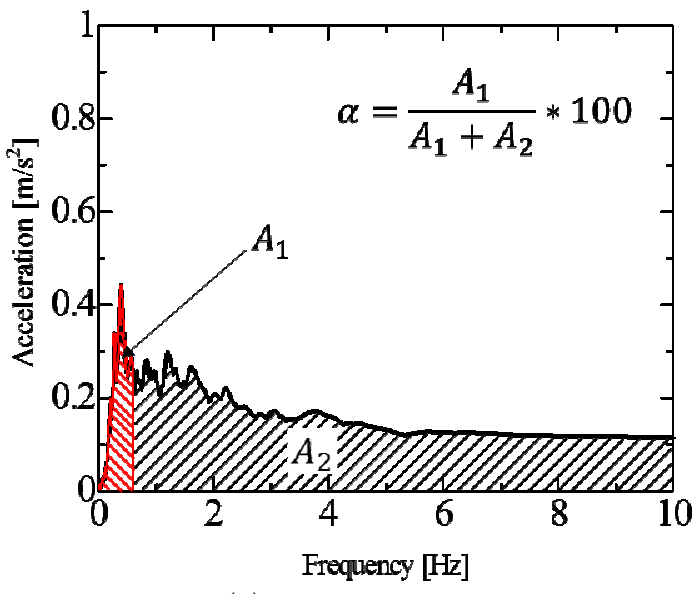

(b) T2AICNS

Fig.12 Response spectrum. The area from $0 \mathrm{~Hz}$ to $0.6 \mathrm{~Hz}$ is defined as $\mathrm{A}_{1}$. The area from $0.6 \mathrm{~Hz}$ to $10 \mathrm{~Hz}$ is defined as $A_{2} . \alpha$ is a value obtained by dividing $A_{1}$ by sum of $A_{1}$ and $A_{2}$.

$$
\alpha=\frac{A_{1}}{A_{1}+A_{2}} * 100
$$

\section{$4 \cdot 4$ 摩擦係数と最大応答加速度, 最大応答相対変位との関係}

最適な摩擦係数を検討するために表 3 に示寸各地震波を対象として静摩擦係数を 0 から 0.5 まで 0.001 刻みに変 化させ, 各摩擦係数における最大応答加速度, 最大応答相対変位を計算した. 動摩擦係数は正弦波加振実験の結 果から静摩擦係数の 0.43 倍とした. 代表的な地震波の最大応答加速度, 最大応答相対変位をプロットしたものを 図 13 に示寸.この図は傾向を見や寸いように地震波の最大加速度を $3 \mathrm{~m} / \mathrm{s}^{2}$ で基準化している. 図 13 より応答加 速度は $\alpha$ の值によって異なる傾向があることがわかる. 短周期成分が卓越した地震動（Nakatane）では摩擦係数 を増加させると応答加速度も増加している. 長周期成分が卓越した地震動（T2AICNS）では摩擦係数を増加させ ると応答加速度は減少する. $\alpha$ の值が Nakatane と T2AICNS の間にある地震動（HACNS）は摩擦係数が 0.1 付近 までは応答加速度が減少し，それ以降は増加している. 他の地震波でも $\alpha$ の值によって同様の傾向を示した. ま たこの図から，応答相対変位は $\alpha$ の值に関わらず，摩擦係数が大きくなると減少する傾向が見られた.

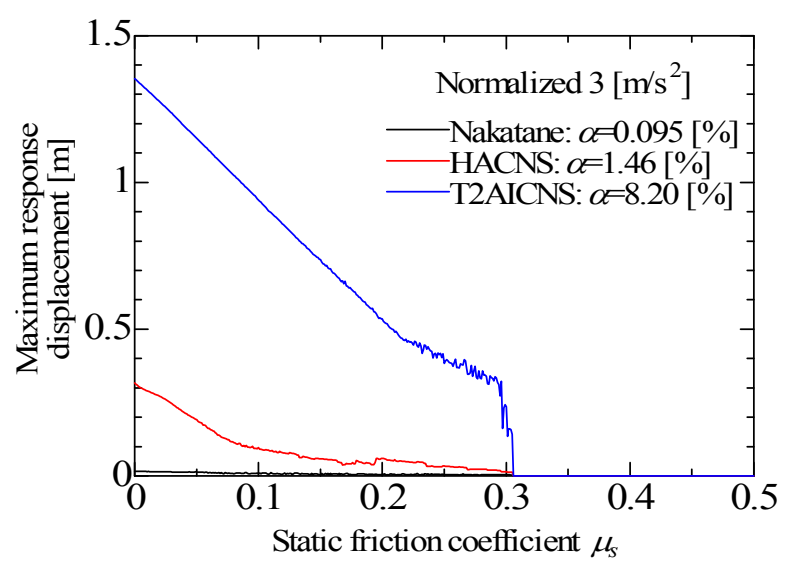

(a) Relative displacement

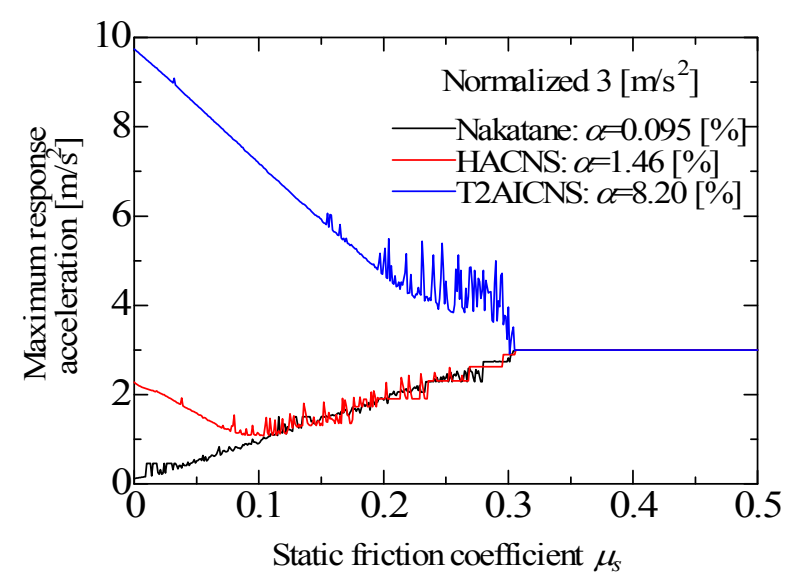

(b) Acceleration

Fig.13 Relation between friction coefficient and maximum response. Tendency of acceleration and relative displacement varies with $\alpha$. Maximum acceleration of input earthquake is normalized to $3 \mathrm{~m} / \mathrm{s}^{2}$. 


\section{$4 \cdot 5$ 最適摩擦係数の検討}

相対変位の低減のみを考えれば，摩擦係数は大きい方が良いが，特に短周期成分が卓越した地震動では摩擦係 数が大きいと応答加速度が増加してしまう. 応答加速度が最も小さくなる摩擦係数を最適摩擦係数として, 横軸 に最大地震加速度, 縦軸に最適摩擦係数をとったものを図 14 に示寸. 従来の研究 (新谷他, 2006 ; 新谷, 服部, 2007）では地震波の最大加速度が大きくなると, 最適摩擦係数も大きくなる傾向があることと地震波の周波数特 性によりばらつきが生じることが報告されている，この報告で使用された地震波は本報で定義した $\alpha$ が $0.0224 \%$ から $1.46 \%$ 程度の短周期成分が卓越した地震動がほとんどであった. 図 14 から, 過去の報告で使用された低周 波数成分含有率の地震波をみてもかなりのばらつきがある.この原因のひとつは摩擦モデルや免震装置の固有周 期の違いによるものと考えられる. 最適摩擦係数は $\alpha$ が小さいと最大地震加速度に対する傾きが小さく， $\alpha$ が大 きくなるにつれ，最大地震加速度に対する傾きが大きくなる傾向が認められる.

図 14 における各值の傾き（最適摩擦係数を最大地震加速度で除したもの）と $\alpha$ の関係を図 15 に示寸. 図中の 式は解析值と計算式の係数を変化させて最小二乗法で求めた. $\alpha$ が小さいときには傾きが $\alpha$ の増加とともに増え, $\alpha$ が大きくなると傾きがほぼ一定となることがわかる。つまり最適摩擦係数に対する $\alpha$ の影響は $\alpha$ が大きくなる につれ小さくなることを示寸，このことから，長周期成分がある程度多くなってくると最適摩擦係数を決定する うえで必要なことはほとんど最大地震加速度のみになることがわかる.図 15 の関係から長周期成分が多い場合は 傾きが 0.1 程度でほぼ一定になっている. また, 長周期地震動のほとんどでは最大地震加速度が $1\left[\mathrm{~m} / \mathrm{s}^{2}\right]$ 程度以下 であるため, 免震装置を設計するうえで長周期地震動を考慮しても摩擦係数は 0.1 以下で十分であると考えられ る.

図 14 に示す最大地震加速度と最適摩擦係数の関係を今求めた係数を用いて整理した結果を図 16 に示す．この 図をみるとほぼ直線関係になっていることがわかる。この図は，最適な摩擦係数は地震波の最大加速度だけでな く，低周波数成分含有率 $\alpha$ にも依存することを示している.

図 17 に $\alpha$ が 0 から $0.5 \%$ ，0.5 から $1 \%$ ，1 から $2 \%$ の群に分け，それぞれの群における低減率（=（1-最大応答 加速度 / 最大地震加速度) *100)（新谷, 奥山, 2011）の平均值を摩擦係数ごとに示した. 使用した地震波は $3 \mathrm{~m} / \mathrm{s}^{2}$ に基準化している．この図から， $\alpha$ が大きくなるにつれ摩擦係数が小さい範囲で低減率が下がることがわかる. また， $\alpha$ が小さい場合は摩擦係数が小さい方が低減率は大きくなる． $\alpha$ が $2 \%$ 以の地震波を対象とすれば，摩擦 係数を 0.05 から 0.1 程度にすれば良いと考えられる. この場合, $\alpha$ が小さい群の地震波では低減率が低下してし まうが，低減率が $70 \%$ 程度であった。

実際に免震装置を設計する際には, 免震装置の許容变位, 免震される機器の許容加速度や想定する地震動（大 きさ，周波数）などを考慮して，摩擦係数を決定する必要がある.

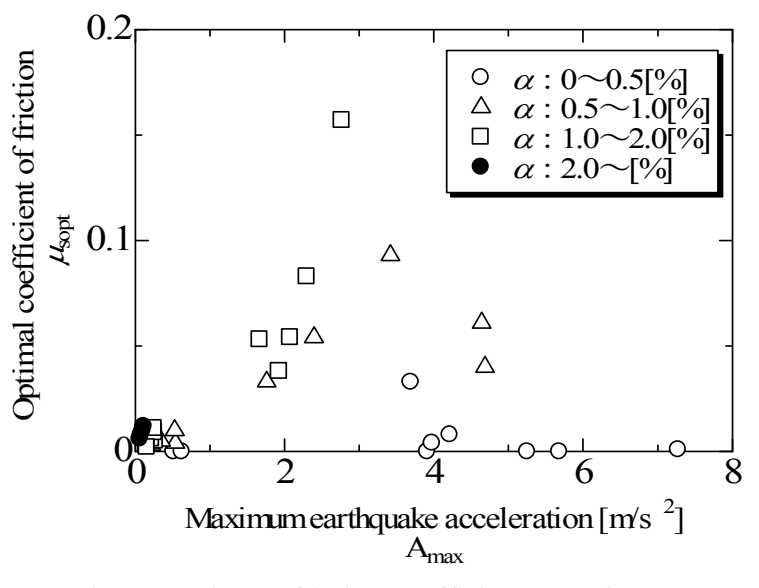

Fig.14 Optimum friction coefficient. As $\alpha$ increases, ratio of the optimum coefficient of friction to maximum earthquake acceleration becomes large.

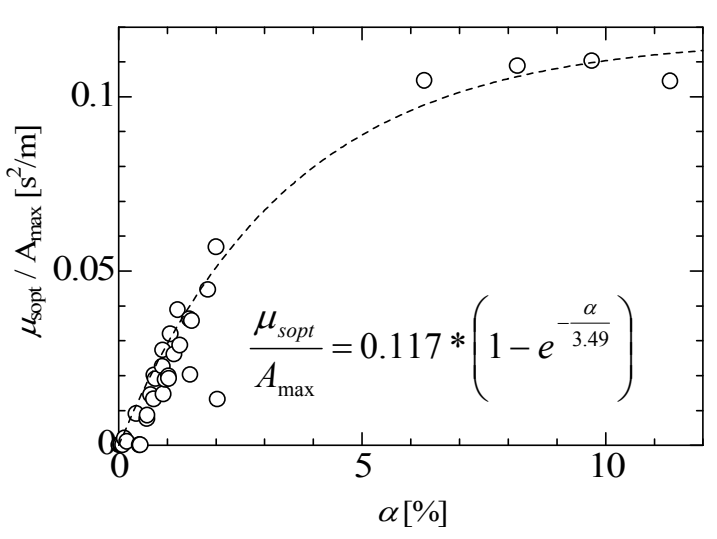

Fig.15 The slope of the optimal coefficient of friction. As $\alpha$ increases, the slope becomes constant. 


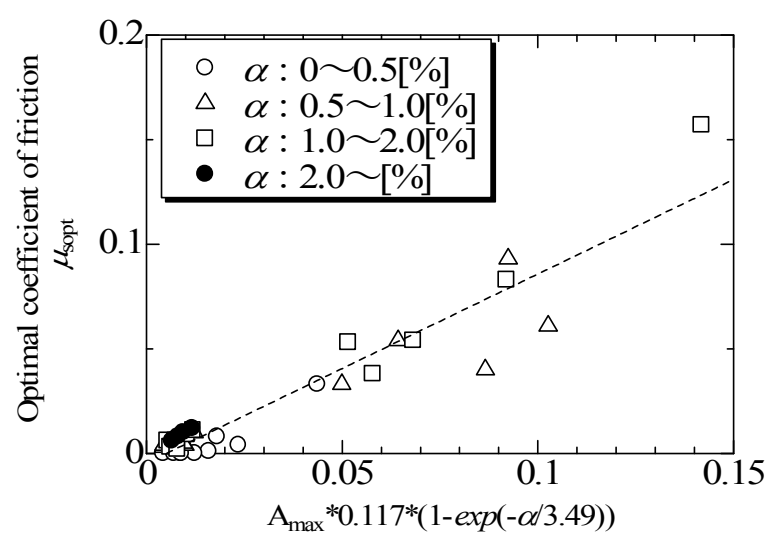

Fig.16 Optimal coefficient of friction. By considering of effect of $\alpha$,relation between the maximum acceleration and optimal friction coefficient is straight line relationship.

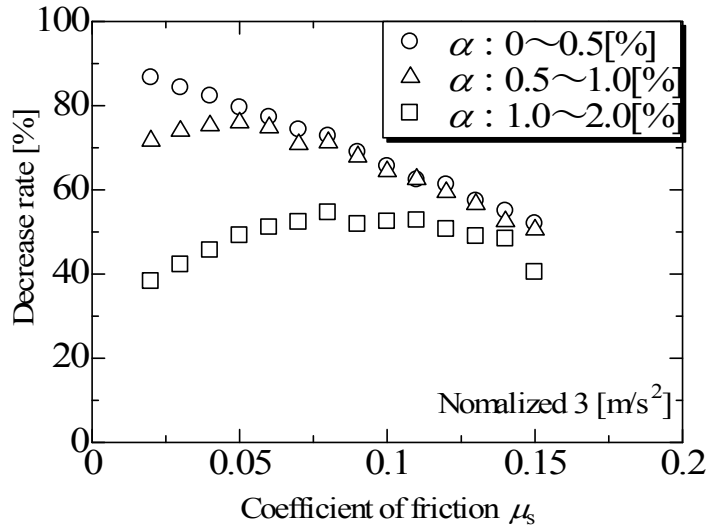

Fig.17 Relation between friction coefficient and seismic isolation effect. As $\alpha$ increases, seismic isolation effect in the area coefficient of friction is small decreases.

\section{5. 結}

本研究では短周期成分が卓越した通常の地震動には大きな免震効果を有し, かつ長周期地震動による免震装置 の共振を防止するため摩擦を利用する方法を提案し, 最適な摩擦係数について検討した. 得られた結果を要約し て以下に示す.

（1） 正弦波加振実験により，摩擦力を与えることで共振点付近では免震装置が停止（相対変位が 0) することを 確認した.

（2）地震波加振実験により，免震装置の静摩擦と動摩擦を考慮した応答解析手法の妥当性を確認した.

（3）低周波数成分含有率 $\alpha$ を定義し，各地震波に免震装置の共振成分がじの程度含まれているかを数值化した.

（4）最適摩擦係数は，最大地震加速度だけでなく低周波数成分含有率に依存することを確認した．最適摩擦係数 とこの低周波数成分含有率に関する補正を行った最大地震加速度とは比例関係にあることが判明した.

（5）低周波数成分含有率 $\alpha$ が $2 \%$ 以下地震波を対象と寸れば最適な摩擦係数は 0.05 から 0.1 であることがわか った.

（6）長周期地震動に対しては，摩擦係数を 0.1 に設定することで相対変位を低減できることがわかった

\section{文献}

気象庁, 各種データ・資料, 震度データベース検索, <http://www. data.jma.go.jp/svd/eqdb/data/shindo/index.php>, (参 照日 2014 年 11 月 25 日)

菊植亮，武居直行，佐野明人，望山洋，藤本英雄，有限時間で零速度に収束する不連続摩擦モデル，ロボティク スシンポジア予稿集 10th (2005), pp.215-220.

防災科学技術研究所，強震ネットワーク K-NET，K-NET，<http://www.k-net.bosai.go.jp/k-net/>，（参照日 2014 年 10 月 9 日).

清水健一, 渡辺孝一, 三浦篤, 西尾浩治, 特殊交差形レール溝方式 免震装置に関寸る研究, 日本機械学会 2014

年度年次大会講演論文集，No.14-1（2014）（DVD 論文集，論文 No.J1010404）。

新谷真功，服部雄一，小寺忠，摩擦による免震装置の研究，日本機械学会論文集 C 編，Vol.72，No.714（2006）, pp.388-393.

新谷真功, 服部雄一, 摩擦面による免震装置の相対変位低減に関寸る研究，日本機械学会論文集 C 編，Vol.73， No.735 (2007), pp.2883-2890.

新谷真功, 田中裕樹，摩擦斜面をもつ免震装置による相対変位低減に関する研究，日本機械学会 Dynamics \& 
Design Conference 2008， No.08-14（2008）（CD-ROM 論文集，論文 No.419）.

新谷真功, 奥山岬, 地震加美術品を守る小型三次元免震装置の開発, 日本機械学会 2011 年度年次大会講演論文 集，No.11-1（2011）（DVD 論文集，論文 No.J101024）.

財団法人日本建築センター, 地震波のダウンロード, 地震波ダウンロードページ, $<\mathrm{http}: / /$ www.bcj.or.jp/download/wave.html>, （参照日 2008 年 3 月 5 日）.

若林信宏, 萩原哲夫, 堀端明雄, 佐藤千助, 朝日崇, 大亦絢一郎, 長周期地震動を考慮した免震テーブルの開発,

日本機械学会論文集 C 編，Vol.77，No.783 (2011)，pp.4090-4099.

\section{References}

Japan Meteorological Agency, Various data and documents, Seismic intensity database search, available from $<$ http://www.data.jma.go.jp/svd/eqdb/data/shindo/index.php>, (accessed on 25 November, 2014).

Kikuuwe, R., Takesue, N. Sano, A., Mochiyama, H. and Fujimoto, H., Discontinuous friction model with finite-time convergence to zero-velocity, Robotics symposia 10th (2005), pp.215-220 (in Japanese).

National Research Institute for Earth Science and Disaster Prevention, Kyoshin Network, K-NET, (online), available from $<$ http://www.k-net.bosai.go.jp/k-net/>, (accessed on 9 October, 2014).

Shimizu, K., Watanabe, K., Miura, A. and Nishio, K., A study on seismic isolation system with special cross railed groove method, Transactions of the Japan Society of Mechanical Engineers, No.14-1 (2014) (DVD No.J1010404) (in Japanese).

Shintani, M., Hattori, Y. and Kotera, T., Study on isolation device by friction, Transactions of the Japan Society of Mechanical Engineers, Series C, Vol.72, No.714(2006), pp.388-393 (in Japanese).

Shintani, M. and Hattori, Y., Study on isolation device for decrease of displacement by using control of friction, Transactions of the Japan Society of Mechanical Engineers, Series C, Vol.73, No.735(2007), pp.2883-2890 (in Japanese).

Shintani, M. and Tanaka, Y., Study on reducing relative displacement of isolation device with friction surface of inclination, Proceedings of the Dynamics \& Design Conference 2008, No.08-14 (2008) (CD-ROM No.419) (in Japanese).

Shintani, M. and Okuyama, M., Development of small three-dimensional seismic isolation device, Mechanical Engineering Congress, 2015 Japan, No.11-1 (2011) (DVD No.J101024) (in Japanese).

The Building Center of Japan, Down Load of Earthquake Waves, (online), available from $<$ http://www.bcj.or.jp/download/wave.html>, (accessed on 5 March, 2008).

Wakabayashi, N., Hagiwara, T., Horibata, A., Sato, S., Asahi, T. and Ohmata, K., Development of seismic isolation table taking accunt of long-period seismic ground motions, Transactions of the Japan Society of Machanical Engineers, Series C, Vol. 77, No. 783 (2011), pp.4090-4099 (in Japanese). 